\title{
Pathogenicity and Molecular Characterization of Staphylococcus aureus Strains Isolated from the Hospital Environment of $\mathrm{CHU}-\mathrm{Z}$ Abomey-Calavi/Sô-Ava (Benin)
}

\author{
Akim Socohou, ${ }^{1}$ Haziz Sina $\mathbb{D D}^{1}{ }^{1}$ Cyriaque Degbey, ${ }^{2}$ Tomabu Adjobimey, ${ }^{3}$ Edna Sossou, ${ }^{1}$ \\ Bawa Boya, ${ }^{1}$ Christine N'tcha, ${ }^{1}$ Hubert Adoukonou-Sagbadja, ${ }^{4}$ Adolphe Adjanohoun, ${ }^{5}$ \\ and Lamine Baba-Moussa ${ }^{1}{ }^{1}$ \\ ${ }^{1}$ Laboratory of Biology and Molecular Typing in Microbiology, Department of Biochemistry and Cell Biology, Faculty of Sciences \\ and Techniques, University of Abomey-Calavi, 05 BP 1604 Cotonou, Benin \\ ${ }^{2}$ Regional Institute of Public Health, University of Abomey-Calavi, Benin; BP 384 Ouidah, Benin \\ ${ }^{3}$ Biochemistry and Molecular Biology Unit, Department of Biochemistry and Cellular Biology, Faculty of Sciences and Techniques, \\ University of Abomey-Calavi, 05 BP 1604 Cotonou, Benin \\ ${ }^{4}$ Department of Genetics and Biotechnology, Faculty of Science and Technology (FAST), University of Abomey-Calavi (UAC), BP, \\ 1947 Cotonou, Benin \\ ${ }^{5}$ National Institute of Agronomic Research of Benin, Benin
}

Correspondence should be addressed to Lamine Baba-Moussa; laminesaid@yahoo.fr

Received 20 February 2021; Revised 15 April 2021; Accepted 26 July 2021; Published 6 August 2021

Academic Editor: Khalid Mehmood

Copyright (C) 2021 Akim Socohou et al. This is an open access article distributed under the Creative Commons Attribution License, which permits unrestricted use, distribution, and reproduction in any medium, provided the original work is properly cited.

\begin{abstract}
Staphylococcus aureus is a major human pathogen present on a third of the healthy population. The bacterium possesses an extensive arsenal of virulence factors. The pathogenicity is linked with $S$. aureus high plasticity and its exceptional ability to incorporate foreign genetic material. The aim of the present study was to perform molecular characterization of Staphylococcus aureus strains isolated from the clinical environment of the CHU-Z Abomey-Calavi/Sô-Ava. Isolation of Staphylococcus aureus bacterium was performed on Chapman agar. Toxin production by isolated $S$. aureus strains was investigated using the radial immunoprecipitation technique. A colorimetric assay was used to evaluate Staphylococcus aureus lipase (SA-Lipase) production. Finally, the expression of antibiotic resistance genes and genes encoding toxins production was investigated. Our data suggest that none of the isolated Staphylococcus aureus strains expressed the investigated toxin genes. Interestingly, SA-Lipase was produced by $14.28 \%$ of our isolated S. aureus strains. The mecA gene was present in $57.14 \%$ of the isolated strains, while PVL and TSST-1 genes were identified in 2.85 and $7.14 \%$ of $S$. aureus, respectively. Significant genetic diversity was observed along the hospital environment $S$. aureus strains. The present study reveals the level of virulence of $S$. aureus strains isolated in the different units of CHU-Z Abomey Calavi/Sô-Ava through the production of lipase, PVL, and epidermolysins. The molecular study has favored a genetic characterization within the isolated strains.
\end{abstract}

\section{Introduction}

Staphylococcus aureus bacterium is often encountered in human pathology and is the causative agent of a wide variety of infections including life-threatening toxic shock syndrome, pneumonia, and sepsis. The clinical outcome of these infections depends on numerous virulence factors that $S$. aureus can produce. Staphylococcal infections represent a major public health problem both because of the bacteria's virulence and the emergence of multiresistant strains [1]. Thus, S. aureus infections are challenging both in terms of diagnosis and therapeutic strategies [2]. Furthermore, Staphylococcus resistance to methicillin is mainly attributed to the acquired mec $\mathrm{A}$ gene [3]. In addition, a new mecC gene has 
recently emerged especially in S. aureus of animal origin [4]. Several studies show that multidrug-resistant $S$. aureus strains are involved in infections and hospital-related deaths in both industrialized and developing countries [5].

In addition, the pathogenicity of this bacterium is linked to the expression of virulence factors [6]. Indeed, S. aureus can produce various heat-resistant extracellular protein toxins that behave as virulence factors, including superantigens, hemolysins, and leukocidins. The most important of these factors is the Panton-Valentine leukocidin (PVL), which is a cytotoxin that forms pores in the membrane and has been associated with boils, skin abscesses, and severe necrotic skin infections $[7,8]$. Some of the pathogenic $S$. aureus strains also possess the gene coding for staphylococcal toxic shock toxin (TSST-1) [9]. These toxins have superantigenic activities and are capable of polyclonal T-cell activation independently of their antigenic specificity. This activation is directly linked to the clinical signs of staphylococcal toxic shock $[10,11]$. It has been shown that the secretion of these toxins by strains in infections constitutes a risk of prolonged hospitalization periods [12].

$S$. aureus can produce abundant amounts of secreted glycerol ester hydrolase (lipase) enzymes, which release free fatty acids from triglycerides [13]. Indeed, some triglycerides contain additional toxic fatty acids that appear to interfere with cell growth by altering cell permeability, cutting off oxidative phosphorylation, or blocking electron transport [14]. This broad array of pathogenic profiles is linked to the high genomic plasticity of $S$. aureus, which confers to the bacteria an exceptional ability to incorporate exogenic genetic material from other strains and thus to acquire new properties, including antibiotic resistance and virulence [13]. All these factors make S. aureus a predominant nosocomial pathogen among immunecompromised patients in hospital environments and health care facilities [15]. The present study is aimed at evaluating the genetic diversity and virulence capacity of $S$. aureus strains isolated from the hospital environment of CHU-Z Abomey-Calavi/Sô-Ava.

\section{Material and Methods}

2.1. DNA Extraction. A total of 42 S. aureus isolates previously isolates from the hospital environment of CHU-Z Abomey-Calavi/Sô-Ava in Benin [16] were used in this study. Those isolates were collected from five medical units of CHU-Z Abomey-Calavi/Sô-Ava: pediatrics (10 isolates), operating room (7 isolates), neonatology (10 isolates), maternity (8 isolates), and central sterilization room (7 isolates). Purification of isolates DNA was done as previously described by Rasmussen and Morrissey [17]. Briefly, $1.5 \mathrm{ml}$ microcentrifuge tubes containing bacterial strains were centrifuged at $12000 \mathrm{rpm}$ for $5 \mathrm{~min}$, the supernatant was poured, and $500 \mu \mathrm{l}$ of sterile distilled water was added to the bacterial pellet. The mixture was then heated in a dry bath at $95^{\circ} \mathrm{C}$ for $15 \mathrm{~min}$. The tubes were centrifuged again at $12000 \mathrm{rpm}$ for $5 \mathrm{~min}$, and the obtained supernatants were recovered in new tubes. $500 \mu \mathrm{l}$ of absolute ethanol was added, and the tubes were centrifuged at $12000 \mathrm{rpm}$ for $5 \mathrm{~min}$. The DNA pel- lets were suspended in $50 \mu \mathrm{l}$ sterile distilled water and maintained at $4^{\circ} \mathrm{C}$ for immediate use or at $-20^{\circ} \mathrm{C}$ for long-term storage.

2.2. Molecular Identification of S. aureus by the 16S-23S rRNA Gene. The 16S-23S rRNA gene primers [18] were used for the molecular confirmation of the $S$. aureus isolates. The sequences of the primers are $G 1$ (5'-GAAGTCGTAAC AAGG- $\left.3^{\prime}\right)$ and $L 1$ ( $5^{\prime}$-CAAGGCATCCACCGT). The PCR reaction was performed on $25 \mu \mathrm{l}$ containing $20 \mu \mathrm{l} 10 \mathrm{x}$ GoTaq mix (PROMEGA, Madison, WI USA), $1 \mu \mathrm{l}$ primer G1 $(10 \mu \mathrm{M}), 1 \mu \mathrm{l}$ primer $L 1(10 \mu \mathrm{M})$, and $3 \mu \mathrm{l}$ DNA. The amplification program is composed of an initial denaturation $\left(94^{\circ} \mathrm{C}\right.$ for $2 \mathrm{~min}), 30$ cycles of denaturation cycles $\left(94^{\circ} \mathrm{C}, 1 \mathrm{~min}\right)$, hybridization $\left(50^{\circ} \mathrm{C}, 2 \mathrm{~min}\right)$, elongation $\left(72^{\circ} \mathrm{C}, 2 \mathrm{~min}\right)$, and a final elongation $\left(72^{\circ} \mathrm{C}, 7 \mathrm{~min}\right)$. For the classification base on the results, 2 patterns were considered different if 2 or more bands of the electropherogram differed in size.

2.3. Production of Leukotoxins and Epidermolysins. The production of Panton and Valentine Leukotoxin (PVL), LukELukD leukotoxin, and epidermolysins (ETA, ETB) of $S$. aureus isolates was investigated by radial immunoprecipitation [19]. Briefly, fresh S. aureus colonies were cultured in $500 \mu \mathrm{l}$ of Yeast Casamino-acid Pyruvate (YCP) broth in 12well culture plates and incubated at $37^{\circ} \mathrm{C}$ for $18-24$ hours under agitation $(200 \mathrm{rpm})$. The content of each well was poured into microcentrifuge tubes, and culture supernatants were collected (using a micropipette) after centrifugation at $5,000 \mathrm{rpm}$ for $5 \mathrm{~min}$. On a $0.6 \%$ agarose gel, 7 wells spaced $8 \mathrm{~mm}$ were dug in a rosette. Approximately $30 \mu \mathrm{l}$ of each sample is placed in the corresponding outer well, followed by purified rabbit anti-leukotoxin (PVL and LukE-LukD) and antiepidermolysins (ETA and ETB) antibodies $(\mathrm{OD}=3)$, placed in the rosette's central well as control antigens $(\mathrm{OD}=0.2)$ in the upper and lower wells in a clockwise direction. After a 16-hour diffusion, the precipitation arcs were viewed directly with the naked eye or after staining with Coomassie blue [19].

2.4. Lipase Production Capability. The procedure described by Janda [20] was used to detect the production of lipolytic enzymes in which polyoxyethylene sorbitan monooleate (Tween 80) is used as a lipid substrate. This method is based on the precipitation of the calcium crystals salt in presence of fatty acid induced by lipase. If the bacterial strain has a lipolytic enzyme, the calcium soap crystals' precipitation will be visible as an opaque halo around the colonies. In addition, if the lipase activity is intense, the precipitation will appear as crystals visible to the naked eye.

The bacterial strains are therefore inoculated on nutrient agar supplemented with Tween 80 . The substrate is added to the culture medium, previously sterilized, at a concentration of $1 \%$. The appearance of opaque precipitation around bacterial colonies occurs after 24 to 72 hours of incubation at $37^{\circ} \mathrm{C}$.

2.5. Search of mecA Gene. The primers used to target the mecA gene were those designed by Malik et al. [21]. The primers sequences are mecA F: $5^{\prime}$ - TCCAGGAATGCAGA 
AAGACC- $3^{\prime}$ and mecA R: $5^{\prime}$-TCACCTGTTTGAGGGT GGAT $-3^{\prime}$. The $25 \mu \mathrm{l}$ reaction mixture contained $20 \mu \mathrm{l}$ GoTaq mix 10x (PROMEGA, Madison, WI USA), $1 \mu \mathrm{l}$ primer F $(10 \mu \mathrm{M}), 1 \mu \mathrm{l}$ primer $\mathrm{R}(10 \mu \mathrm{M})$, and $3 \mu \mathrm{l}$ DNA.

The amplification program is initial denaturation $\left(94^{\circ} \mathrm{C}\right.$, $3 \mathrm{~min}), 35$ cycles of denaturation $\left(94^{\circ} \mathrm{C}, 1 \mathrm{~min}\right)$, hybridization $\left(55^{\circ} \mathrm{C}, 1 \mathrm{~min}\right)$, elongation $\left(72^{\circ} \mathrm{C}, 1 \mathrm{~min}\right)$, and a final elongation $\left(72^{\circ} \mathrm{C}, 10 \mathrm{~min}\right)$. The expected fragment size of the PCR product is $675 \mathrm{bp}$.

2.6. Detection of Genes Encoding the Production of Toxins. In order to confirm certain immunological results, the presence of genes encoding Panton and Valentine Leukotoxin (PVL: F: $5^{\prime}$-AAATGCCACTGTTATCCAGAGGTA-3' and R: $5^{\prime}-\mathrm{T}$ TTGCAGCGTTTTGTTTTCG-3') and Toxic Shock Syndrome Toxin 1 (TSST-1: F: $5^{\prime}$ - ACCCCTGCCTTTCCAT CATC-3' and R: $5^{\prime}-\mathrm{T}$ TTTCAGTATTTGTAACGCC- $3^{\prime}$ ) was investigated using specific primers. The $25 \mu \mathrm{l}$ reaction mixture contained $18 \mu \mathrm{l}$ GoTaq mix 10x (PROMEGA, Madison, WI USA), $1 \mu \mathrm{l}$ primer (LPV) $\mathrm{F}(10 \mu \mathrm{M}), 1 \mu \mathrm{l}$ primer (LPV) R $(10 \mu \mathrm{M}), 1 \mu \mathrm{l}$ primer (TSST-1) $\mathrm{F}(10 \mu \mathrm{M}), 1 \mu \mathrm{l}$ primer (TSST-1) R $(10 \mu \mathrm{M})$, and $3 \mu \mathrm{l}$ DNA. The toxin amplification program was initial denaturation $\left(92^{\circ} \mathrm{C}, 2 \mathrm{~min}\right), 35$ cycles of denaturation $\left(92^{\circ} \mathrm{C}, 2 \mathrm{~min}\right)$, hybridization $\left(50^{\circ} \mathrm{C}\right.$, $1 \mathrm{~min})$, elongation $\left(72^{\circ} \mathrm{C}, 2 \mathrm{~min}\right)$, and a final elongation $\left(72^{\circ} \mathrm{C}, 3 \mathrm{~min}\right)$.

2.7. Data Analysis and Processing. The data collected was coded and processed using Microsoft Excel 2013 spreadsheet software. Graph Pad Prism 7 software was used for comparison testing of positive isolates at various collection sites. $\mathrm{R}$ software was used for correspondence factor analysis and then using the results of this analysis for dendrogram clustering. Significance was accepted when $p<0.05$.

\section{Results}

\subsection{Genotypic Characterization of S. aureus Strains}

3.1.1. Genotypic Identification of S. aureus by 16S-23S rRNA. Observation of UV gels after amplification reveals the presence of several bands within isolated $S$. aureus strains. The number of bands varies from 2 to 4 bands in our study. Band sizes range from about $300 \mathrm{bp}$, about $350 \mathrm{bp}$, and about 447 to $569 \mathrm{bp}$ (Figure 1). However, the predominant characteristic stamp was the presence of both bands $(447 \mathrm{bp}$ and $569 \mathrm{bp}$ ). This confirms that 35 strains out of 42 were effectively Staphylococcus aureus.

Using the polymorphism based on the size and number of bands, the studied S. aureus isolates were classified. Thus, considering scale 1, three phylogenetic subgroups of Staphylococcus aureus were obtained (Figure 2). Notable was that the strains of $S$. aureus that make up subgroup 1 are related and originate from the five services studied. On the other hand, strains in subgroup 2 were from the neonatal, pediatric, and maternity wards. Furthermore, subgroup 3 comprises strains from four services (central sterilization, operating room, maternity, and neonatology).

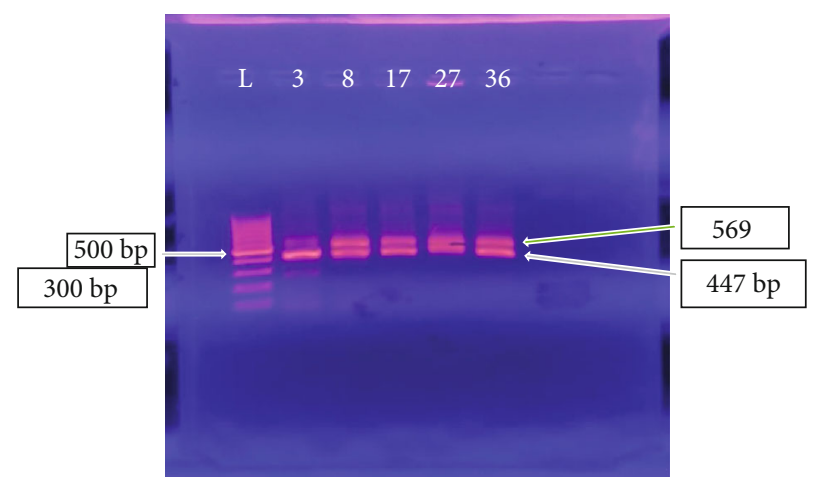

Figure 1: Photo showing the bands of the 16S-23S rRNA gene. L: Molecular weight marker; $S$. aureus samples: $(3,8,17,27,36)$.

\subsection{Toxigenic Profile of Isolated S. aureus Strains}

3.2.1. Phenotypic Production of Toxins and Lipase. On reading the immunoprecipitation test, it appears that no strain of $S$. aureus produces PVL toxin, and the same observation was made for epidermolysin A (ETA) and epidermolysin B (ETB) (Table 1). On the other hand, the lipase test revealed that at least one strain in each of the departments such as pediatrics, neonatology, and central sterilization has produced lipase, but in the maternity ward, 2 strains were observed to produce lipase (Table 1). However, the strains of $S$. aureus isolated in the operating theatre did not produce lipase. In general, $14.28 \%$ of the S. aureus strains isolated in the hospital environment were lipase-producing.

3.2.2. Detection of the mecA, LPV, and TSST-1 Gene. After PCR, the distribution of the presence of the mecA gene by service shows that bacterium isolated in neonatology are more carriers of the mecA resistance gene, followed by maternity and pediatrics (Table 2). On the other hand, it appears that only one strain of $S$. aureus has the Panton and Valentine leukotoxin (PVL) gene. This strain with the PVL gene is isolated in the maternity ward. In contrast, for the TSST-1 gene, three strains of $S$. aureus possess this gene and are from pediatrics, maternity, and central sterilization (Table 2).

Globally, it should be noted that $57.14 \%$ of our S. aureus strains have the methicillin resistance gene (mecA) in their genome. $2.85 \%$ and $8.57 \%$ represent the proportion expressing the PVL and Toxic Shock Toxin genes, respectively (Figure 3).

\section{Discussion}

The molecular technique showed large importance of its use since 7 strains were not $S$. aureus. The 16S-23S ribosomal RNA gene can be said to be a target of choice and useful for better strain identification [22]. The reason for the genetic polymorphism (band size and number of bands) linked to the 16S-23S rRNA gene observed in our study is due to the presence of multiple copies of this gene in S. aureus strains. Several authors have shown that $S$. aureus was the species with the highest number of polymorphisms $[18,23,24]$. 


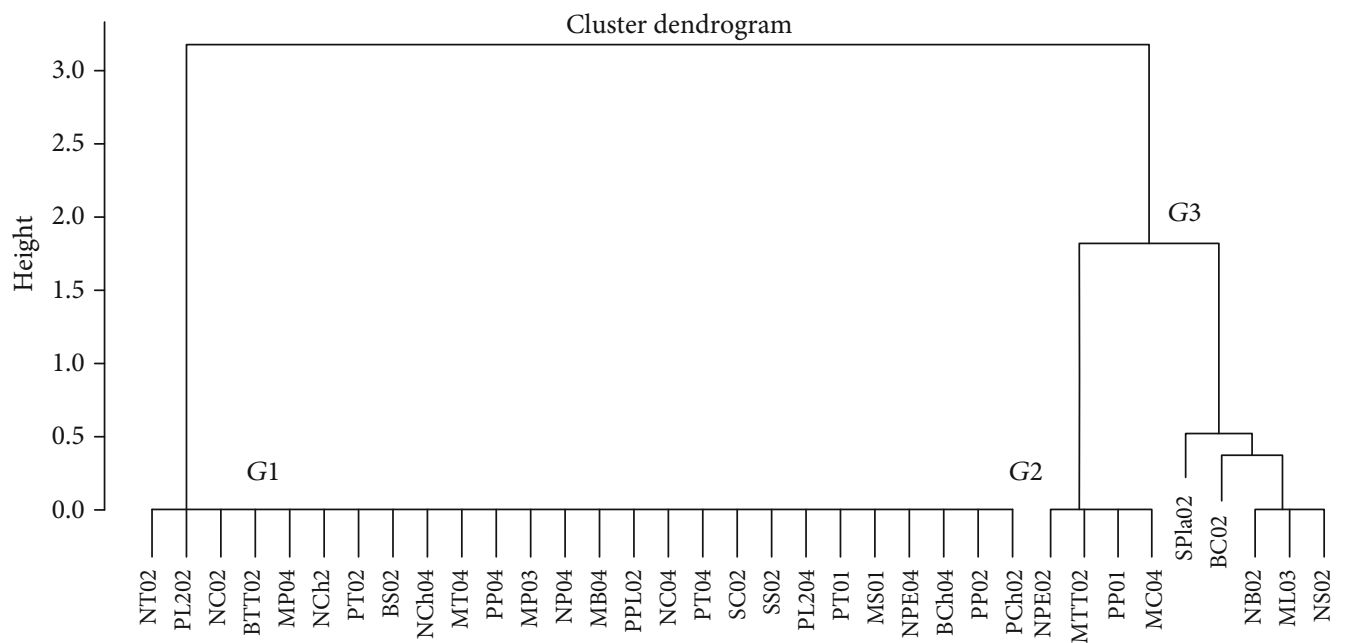

FIGURE 2: Genetic diversity dendrogram as a function of the 16S-23S rRNA gene. The initials indicate the service: N: neonatology; M: maternity; P: pediatrics; B: operating room; S: central sterilization.

TABLE 1: Production of virulence factors by service.

\begin{tabular}{|c|c|c|c|c|c|c|}
\hline \multirow{2}{*}{ Virulence factors } & \multicolumn{6}{|c|}{ Services } \\
\hline & Pediatrics & Maternity & Neonatology & Operating room & Central sterilization & Total \\
\hline PVL & 0 & 0 & 0 & 0 & 0 & $0 / 35$ \\
\hline ETA & 0 & 0 & 0 & 0 & 0 & $0 / 35$ \\
\hline ETB & 0 & 0 & 0 & 0 & 0 & $0 / 35$ \\
\hline Lipase & 1 & 2 & 1 & 0 & 1 & $5 / 35$ \\
\hline
\end{tabular}

TABLE 2: Result of the search for virulence genes.

\begin{tabular}{|c|c|c|c|c|c|c|}
\hline \multirow{2}{*}{ Gene sought } & \multicolumn{6}{|c|}{ Services } \\
\hline & Pediatrics & Maternity & Neonatology & Operating room & Central sterilization & Total \\
\hline $\mathrm{MecA}$ & 5 & 5 & 7 & 2 & 1 & $20 / 35$ \\
\hline PVL & 0 & 1 & 0 & 0 & 0 & $1 / 35$ \\
\hline TSST-1 & 1 & 1 & 0 & 0 & 1 & $3 / 35$ \\
\hline
\end{tabular}

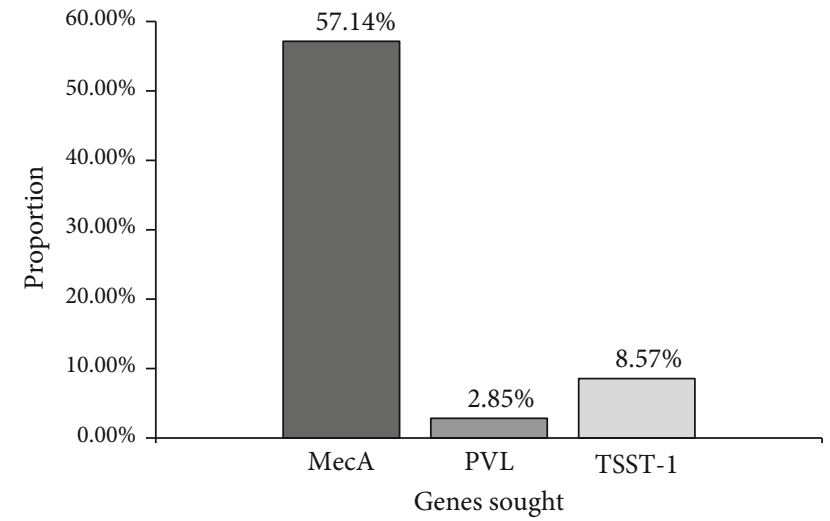

Figure 3: Proportion of genes searched.

Furthermore, the characteristic band profile (about $447 \mathrm{bp}$ and $569 \mathrm{bp}$ ) is also observed in the work of Mendoza et al. [25] and Akineden et al. [26].
Concerning the pathogenicity of $S$. aureus, one of the strategies adopted by host cells to respond to infection is the production of fatty acids and lipids, which form small holes in the bacterial membrane. In contrast, $S$. aureus produces enzymes called lipases that destroy these fatty acids before causing damage to the bacterial membrane [27]. It appears that $14.28 \%$ of our $S$. aureus strains are lipase producers. This result could be explained by the low use of fats in the composition of detergents used in surface cleaning. Also, lipase production in the test with Tween 80 is justified by the stimulating effect of $\mathrm{Ca}^{2+}$ present in the medium in $S$. aureus. This is confirmed by Bornsheur et al. [28], who state that bivalent cations such as calcium often stimulate the enzymatic activity of lipase. Recent work by Cadieux et al. [29] reported lipase production by strains of S. aureus, S. hycus USA 300, and Pogaku et al. [30] in Staphylococcus sp. Lp12 strains. Therefore, this virulence factor deserves more attention because microbial lipases are highly stable to temperature, detergents, and certain proteolytic enzymes [31]. 
The phenotypic results on the nonproduction of PVL, ETA, and ETB toxins by our $S$. aureus strains are partly reassuring. The same observations were made by Ahoyo et al. [32] in S. aureus strains isolated in the hospital environment in central Benin and by Sina et al. [33] in S. aureus isolated from catheters at the CNHU of Cotonou. On the other hand, many clinical strains isolated from body fluids produce PVL up to more than $50 \%$ of the bacterium isolated $[33,34]$. This difference could be due to the fact that strains isolated from body fluids are often confronted to the immune system and have developed this virulence factor. However, molecular PCR assays showed that only one strain had the PVL gene, and three strains of $S$. aureus had the TSST-1 gene. And the mere fact that these strains came from the pediatric and maternity wards is worrisome given the proximity of the two wards in the hospital and the risk of probable gene transfer. Our results on the presence of the PVL gene are different from the 7.14\% obtained by Cadé et al. [35] in France. For the TSST-1 gene, the $7.14 \%$ obtained in our study is slightly higher than the 3.3\% obtained by Baba-Moussa et al. [7] in $S$. aureus isolated from dermatoses.

This variation could be attributed to the level of pathogenicity of the strains or the geographical location but also to the difference in gene detection methods. Although the pathogenicity of these strains does not appear to be related to the production of PVL based on the immunological results obtained, it is easy to understand that the presence of the genes that can promote the expression of these different toxins is associated with an increase in virulence of certain strains of $S$. aureus [2]. Thus, the primary concern remains in the possibility of horizontal transfer of these genes and their possible expression within $S$. aureus species, which could promote the spread of virulent strains in the coming years. In addition, certain hereditary immune deficiencies are associated with severe PVL+ staphylococcus infections: chronic septic granulomatosis, leukocyte adhesion defects, congenital neutropenia, and innate immunity defects. However, these strains (PVL+) are known to be responsible, particularly in nonimmunocompromised children, for necrotizing pneumopathies, rapid progression, and poor prognosis despite appropriate antibiotic therapy [36].

However, methicillin resistance is also one of the criteria for virulence of Staphylococcus aureus. Indeed, the phenotypic expression of methicillin resistance is influenced by several parameters (mean temperature, $\mathrm{pH}$, and $\mathrm{NaCl}$ content in the medium and even genotypic). Thus, the presence of the mecA gene by the molecular method gives a clearer idea of the MRSA strains in our samples. We deduce that at least half of the $S$. aureus strains isolated from neonatal, maternity, and pediatric wards are carriers of the mecA gene. The contiguous nature of these three departments would be a critical factor in bringing the three departments closer together, thus, favoring a probable transfer of the mecA gene and also the diffusion of its resistant bacterium through the movement of staff from one department to another or of patients from one department to another.

Overall, $57.14 \%$ of isolated $S$. aureus possess the mecA gene. These results are consistent with those of Rocchetti et al. [37], who reported that $50.6 \%$ of S. aureus isolated from blood culture bottles in Brazil had the mecA gene. On the other hand, our results are contrary to those of Sajit Khan et al. [38] in South India, who found that $94 \%$ of clinical MRSA were carriers of the mecA gene. This difference could be explained by a low transfer of the mecA gene within $S$. aureus strains from CHU-Z Abomey-Calavi/Sô-Ava. Furthermore, several studies show that the mecA gene is also present in coagulase-negative staphylococci [37]. It is important that this work can help improve new therapy options to limit the spread of these pathogens. Because hospitalacquired MRSA is also responsible for community-acquired infections in patients with risk factors such as a history of hospitalization [39].

\section{Conclusion}

This work allows to highlight the level of virulence of $S$. aureus strains isolated in the departments of CHU-Z Abomey-Calavi/Sô-Ava through the production of lipase as well as the production of PVL and epidermolysins. PCR research has shown the presence of the mecA gene and the PVL gene in our S. aureus strains. The molecular study favored a genetic characterization within our strains, which allowed a group matching. The acquisition of these virulence factors as well as the genetic background of these strains requires more attention and suggests the necessity of specific hospital measures.

\section{Data Availability}

The data used to support the findings of this work are available from the corresponding author upon request.

\section{Disclosure}

This paper has been extracted from a $\mathrm{PhD}$ thesis by Akim Socohou carried out in Abomey-Calavi University, Benin.

\section{Conflicts of Interest}

The authors declare that they have no conflicts of interest.

\section{Authors' Contributions}

AS, HS, CD, and LB-M conceptualized and designed this study. AS, HS, and ES participated significantly in data acquisition. ES, AT, and $\mathrm{BB}$ performed the statistical analysis under the supervision AA and HA-S. ES, AT, and CN drafted the final manuscript with AA and HA-S. All authors contributed to the revision of the final manuscript and approved submission.

\section{Acknowledgments}

The authors would like to express their gratitude to the staff of the CHU-Z Abomey-Calavi/Sô-Ava (Benin). 


\section{References}

[1] G. Durand, Caractérisation, épidémiologie et pathogénie d'un clone de Staphylococcus aureus résistant à la méticilline portant le gène de la toxine du choc toxique staphylococcique (TSST-1) [Ph.D. thesis], University of Lyon, 2009.

[2] S. Pérez, A. Liaudet, P. B. Favrat, J. Cornuz, and G. Greub, "Staphylococcus aureus producing Panton-Valentine leukocidin : notions in clinical practice," Revue Medicale Suisse, vol. 14, no. 625, pp. 1946-1950, 2018.

[3] H. de Lencastre, A. M. Sa Figueiredo, C. Urban, J. Rahal, and A. Tomasz, "Multiple mechanisms of methicillin resistance and improved methods for detection in clinical isolates of Staphylococcus aureus," Antimicrobial Agents and Chemotherapy, vol. 35, no. 4, pp. 632-639, 1991.

[4] G. K. Paterson, E. M. Harrison, and M. A. Holmes, "The emergence of _mecC_ methicillin-resistant _Staphylococcus aureus_, Trends in Microbiology, vol. 22, no. 1, pp. 42-47, 2014.

[5] T. Kejela and K. Bacha, "Prevalence and antibiotic susceptibility pattern of methicillin-resistant Staphylococcus aureus (MRSA) among primary school children and prisoners in Jimma town, Southwest Ethiopia.," Annals of Clinical Microbiology and Antimicrobials, vol. 12, no. 1, pp. 11-11, 2013.

[6] R. J. Gordon and F. D. Lowy, "Pathogenesis of MethicillinResistantStaphylococcus aureusInfection," Clinical Infectious Diseases, vol. 46, no. s5, pp. S350-S359, 2008.

[7] L. Baba-Moussa, H. Sina, J. M. Scheftel et al., "Staphylococcal Panton-Valentine leucocidin as a major virulence factor associated to furuncles," PLoS One, vol. 6, no. 10, p. e25716, 2011.

[8] A. M. Sultan and Y. Nabiel, "Association of tsst-1 and pvl with mecA genes among clinical Staphylococcus aureus isolates from a tertiary care hospital," Journal of Pure and Applied Microbiology, vol. 13, no. 2, pp. 855-864, 2019.

[9] G. Durand, M. Bes, H. Meugnier et al., "Detection of new methicillin-resistant Staphylococcus aureus clones containing the toxic shock syndrome toxin 1 gene responsible for hospital- and community-acquired infections in France," Journal of Clinical Microbiology, vol. 44, no. 3, pp. 847-853, 2006.

[10] D. L. Stevens, “The toxic shock syndromes," Infectious Disease Clinics North America, vol. 10, no. 4, pp. 727-746, 1996.

[11] J. K. McCormick, J. M. Yarwood, and P. M. Schlievert, "Toxic shock syndrome and bacterial superantigens: an update," Annual Reviews in Microbiology, vol. 55, no. 1, pp. 77-104, 2001.

[12] L. Cupane, N. Pugacova, D. Berzina, V. Cauce, D. Gardovska, and E. Miklasevics, "Patients with Panton-Valentine leukocidin positive Staphylococcus aureus infections run an increased risk of longer hospitalisation," Interantional Journal of Molecular Epidemiology and Genetics, vol. 3, no. 1, pp. 48-55, 2012.

[13] A.-K. Ziebandt, H. Kusch, M. Degner et al., "Proteomics uncovers extreme heterogeneity in the Staphylococcus aureus exoproteome due to genomic plasticity and variant gene regulation," Proteomics, vol. 10, no. 8, pp. 1634-1644, 2010.

[14] N. R. Chamberlain, B. G. Mehrtens, Z. Xiong, F. A. Kapral, J. L. Boardman, and J. I. Rearick, "Correlation of carotenoid production, decreased membrane fluidity, and resistance to oleic acid killing in Staphylococcus aureus 18Z," Infection and Immunity, vol. 59, no. 12, pp. 4332-4337, 1991.

[15] L. Baba-Moussa, L. Anani, J. M. Scheftel et al., "Virulence factors produced by strains of_Staphylococcus aureus_isolated from urinary tract infections," Journal of Hospital Infections, vol. 68 , no. 1, pp. 32-38, 2008.

[16] A. Socohou, H. Sina, C. Degbey et al., "Antibiotics resistance and biofilm formation capacity of Staphylococcus spp. strains isolated from surfaces and medicotechnical materials," International Jouranl of Microbiology, vol. 2020, article 6512106, pp. 1-6, 2020.

[17] R. S. Rasmussen and M. T. Morrissey, "DNA-based methods for the identification of commercial fish and seafood species," Comprehensive Reviws in Food Science and Food Safetay, vol. 7, no. 3, pp. 280-295, 2008.

[18] I. Couto, S. Pereira, M. Miragaia, S. Sanches, and H. de Lencastre, "Identification of clinical staphylococcal isolates from humans by internal transcribed spacer PCR," Journal of Clinical Microbiology, vol. 39, no. 9, pp. 3099-3103, 2001.

[19] A. Gravet, D. A. Colin, D. Keller, R. Giradot, H. Monteil, and G. Prévost, "Characterization of a novel structural member, LukE-LukD, of the bi-component staphylococcal leucotoxins family," FEBS Letters, vol. 436, no. 2, pp. 202-208, 1998.

[20] K. Janda, "The lipolytic activity of _Thermomyces lanuginosus_strains isolated from different natural sources," International Biodeterioration \& Biodegradation, vol. 55, no. 2, pp. 149-152, 2005.

[21] S. Malik, H. Peng, and M. D. Barton, "Partial nucleotide sequencing of the mecA genes of Staphylococcus aureus isolates from cats and dogs," Journal of Clinical Microbiology, vol. 44, no. 2, pp. 413-416, 2006.

[22] S. Chakravorty, D. Helb, M. Burday, N. Connell, and D. A. Alland, "A detailed analysis of $16 \mathrm{~S}$ ribosomal RNA gene segments for the diagnosis of pathogenic bacteria," Journal of Microbiological Methods, vol. 69, no. 2, pp. 330-339, 2007.

[23] R. D. Wojtyczka, D. Krakowian, L. Marek et al., "Analysis of the polymorphism of Staphylococcus strains isolated from a hospital environment," African Journal of Microbiology Research, vol. 5, no. 28, pp. 4997-5003, 2011.

[24] A. Dubey, S. K. Ghorui, and S. K. Kashyap, "Differentiation of S. aureus strains based on $16 \mathrm{~S}-23 \mathrm{~S}$ ribosomal intergenic space polymorphism," Indian Journal of Biotechnology, vol. 8, pp. 276-279, 2009.

[25] M. Mendoza, H. Meugnier, M. Bes, J. Etienne, and J. Freney, "Identification of Staphylococcus species by 16S-23S rDNA intergenic spacer PCR analysis," International Journal of Systematic and Evolutionary Microbiology, vol. 48, no. 3, pp. 1049-1055, 1998.

[26] O. Akineden, A. A. Hassan, E. Schneider, and E. Usleber, "A coagulase-negative variant ofStaphylococcus aureusfrom bovine mastitis milk," Journal of Dairy Research, vol. 78, no. 1, pp. 38-42, 2011.

[27] P. F. Tally, "Les staphylocoques, abcès et autres maladies," in Microbiologie et pathologie infectieuse, pp. 192-193, De Boeck, 1999.

[28] U. T. Bornscheuer, C. Bessler, R. Srinivas, and S. Hari Krishna, "Optimizing lipases and related enzymes for efficient application," Trends in Biotechnology, vol. 20, no. 10, pp. 433-437, 2002.

[29] B. Cadieux, V. Vijayakumaran, M. Bernards, M. McGavin, and D. Heinrichs, "Role of lipase from community-associated methicillin-resistant Staphylococcus aureus strain USA300 in hydrolyzing triglycerides into growth-inhibitory free fatty acids," Journal of Bacteriology, vol. 196, no. 23, pp. 40444056, 2014. 
[30] P. Pallavi, S. A, S. P, and R. R. S, "Optimization of lipase production by Staphylococcus sp. Lp12," The African Journal of Biotechnology, vol. 9, no. 6, pp. 882-886, 2010.

[31] K. E. Jaeger and T. Eggert, "Lipases for biotechnology," Current Opinion in Biotechnololgy, vol. 13, no. 4, pp. 390-397, 2002.

[32] A. T. Ahoyo, L. Baba-Moussa, M. Makoutode et al., "Incidence of meticillin-resistant_Staphylococcus aureus_in neonatal care unit of departmental hospital centre of Zou Collines in Benin," Archives de Pédiatrie, vol. 13, no. 11, pp. 1391-1396, 2006.

[33] H. Sina, F. Baba Moussa, T. A. Ahoyo et al., "Antibiotic susceptibility and toxins production of Staphylococcus aureus isolated from clinical samples from Benin," African Journal of Microbiology Research, vol. 5, no. 18, pp. 2797-2803, 2011.

[34] N. Y. Zinzendorf, L. Baba-Moussa, T. Ouassa et al., "Production de leucotoxines et résistance à la méticilline chez des souches de Staphylococcus aureus isolées à Abidjan," Journal des Sciences Pharmaceutiques et Biologiques, vol. 14, no. 1, pp. 32-40, 2013.

[35] S. Cadé, V. Foissaud, C. Bigaillon et al., “_Staphylococcus aureus_ infections carrying Panton-Valentine leukocidin genes in hospitals: which statute should be given to these strains?," Pathologie Biologie, vol. 55, no. 8-9, pp. 370-374, 2007.

[36] Y. Gillet, B. Issartel, P. Vanhems et al., “Association between _Staphylococcus aureus_strains carrying gene for PantonValentine leukocidin and highly lethal necrotising pneumonia in young immunocompetent patients," Lancet, vol. 359, no. 9308, pp. 753-759, 2002.

[37] T. T. Rocchetti, K. B. Martins, P. Y. F. Martins et al., "Detection of the _mec_A gene and identification of _Staphylococcus_ directly from blood culture bottles by multiplex polymerase chain reaction," Brazilian Journal of Infectious Diseases, vol. 22, no. 2, pp. 99-105, 2018.

[38] S. AK, P. Shetty, L. Y, A. Chidambaram, and R. Ranganathan, "Detection of mecA genes of methicillin-resistant Staphylococcus aureus by polymerase chain reaction," International Journal of Health and Rehabilitation Sciences, vol. 1, no. 2, pp. 64-68, 2012.

[39] A. Tristan, G. Durand, F. Durupt et al., "The epidemiology and evolution of MRSA clones," Revue Francophone des Laboratoires, vol. 2005, no. 376, pp. 75-79, 2005. 